\title{
IBM joins genomics mapping consortium
}

Paris

The ambitions of IBM, the world's largest information technology company, to become a major player in genomics took a step forward last week. The company joined a consortium set up to produce a map of human genetic markers known as singlenucleotide polymorphisms, or SNPs.

This US\$50-million joint effort by drug companies and academic centres, begun last year, aims to generate a map and place it in the public domain by 2001. IBM is the first core information technology company to join, and will pay a subscription of $\$ 3$ million.

"IBM will add sophistication," says Arthur Holden, chairman and chief executive officer of the SNP Consortium. "Bioinformatics has been dominated by biologists with an interest in computing, and genome software is very basic. We really need to harvest more of the mainstream information technology capacities."

Other members include Britain's Wellcome Trust, AstraZeneca PLC, Aventis Pharma, Bayer AG, Bristol-Myers Squibb Company, Hoffman-LaRoche, Glaxo Wellcome PLC, Novartis, Pfizer Inc., Searle, SmithKline Beecham PLC and Motorola Inc.

SNPs are identified and analysed in Britain at the Sanger Centre near Cambridge and in the United States at the Whitehead Institute for Biomedical Research, Washington University School of Medicine, Stanford Human Genome Center, and Cold Spring Harbor Laboratory.

The consortium (http://snp.cshl.org) aims to identify 300,000 SNPs by April 2001, and has mapped 150,000 of them to their positions on the genome. SNPs occur about once in every 1,000 bases of the 3 billion bases in the human genome. They are key to developing genetic medicine, allowing assessment of individuals' predisposition to diseases, and tailoring therapies.

SNPs will help track down the location of genes in disease, when whole-genome scans of populations susceptible to a disease are compared with those of others that are not. The strategy is to take DNA from 24 ethnically diverse individuals, create small representative libraries across the genome, sequence them and compare the overlapping traces.

It will yield "a broad evenly spaced map across the genome representative of diversity", says Holden. He adds that the built-in diversity will yield large numbers of novel SNPs - one problem is that many of the common SNPs have no role in disease.

To allow time for mapping, the consortium plans quarterly releases into the public domain on the dbSNP database (http://www.ncbi.nlm.nih.gov/SNP). The second of these brings the number of mapped SNPS to 7,365.

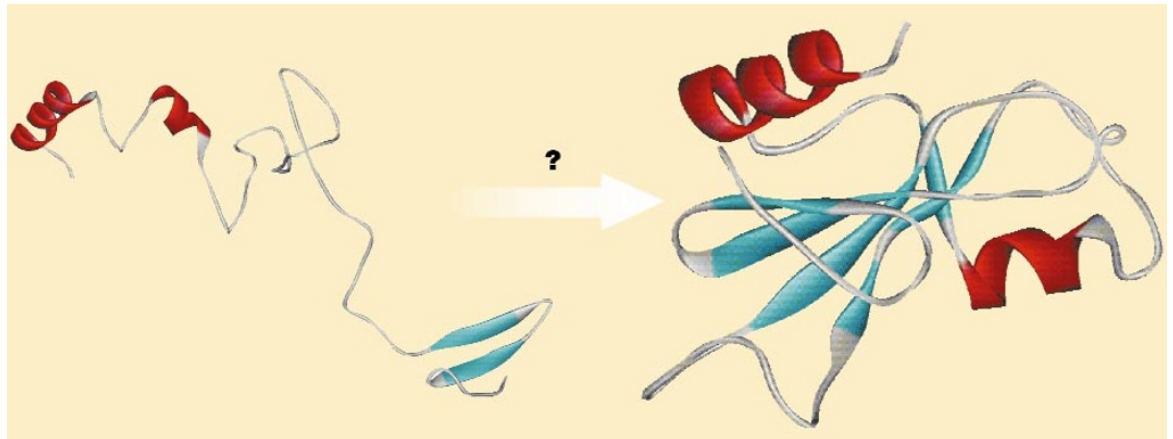

Protein problem: IBM says that its computing power will help researchers work out how unfolded proteins (such as Barnase, left) become the folded form (right).

The research centres have now scaled up to maximum output, says Holden, and 42,000 SNPs have been identified. This acceleration is "fantastic", says Genghis LloydHarris, director of biotechnology and pharmaceutical equity research at Credit Suisse First Boston in London. It will allay concerns that the project was making slower progress than expected in the face of private rivals such as the US company Celera Genomics and France's Genset, he says.

Dan McCurdy, IBM's vice-president for life sciences, says the decision marks IBM's commitment to a public-domain effort. He adds that, if SNPs are to be broadly applicable to diagnosis and treatment, massive datahandling capacities will be needed to screen an explosion in genetic information.

"Hundreds of genomes are going to be sequenced, and today's tools are relatively crude," says Jeff Augen, IBM's director of life science solutions development. Genomics needs more computer science input and a huge increase in computer power, he says.

In return, IBM will "gain a better understanding of the genome industry by sitting on the board and technical committees of the consortium," he says. It is also interested in using SNPs in its own research to see how polymorphisms affect protein folding.

The move follows IBM's launch in December of a $\$ 100$ million research programme built around the challenge of modelling protein folding — to build a petaflop supercomputer within five years (see Nature 402, $705 ; 1999)$. This would carry out more than one quadrillion floating point operations ('flops') per second: some two million times more than the best desktop machines. IBM has also created a life sciences division.

IBM also recently announced $\$ 1$ million grants to pilot centres within the US National Institutes of Health's Protein Structure Initiative, a structural genomics programme established last June. The grants are for IBM RS/6000 SP supercomputers and other technologies, while scientists at the centres would have access to software and other resources at its Deep Computing Institute.

It is too soon to say what IBM's licensing policy for software will be, says McCurdy, but he expects it will make some tools freely available to academics. IBM recently made freely available the source code to its Visualization Data Explorer (http://www.research. ibm.com/dci/software.html). Declan Butler

\section{Rules agreed over GM food exports}

\section{Washington}

Negotiators from 130 countries last week agreed on a Biosafety Protocol that will require exporters to identify genetically modified (GM) organisms, and allow importing countries to judge whether they pose environmental or health risks.

The surprise agreement bridges deep divisions between the United States and Europe on whether GM and non-GM food should be treated differently for trade purposes. It was reached early in the morning of 29 January, after four days of negotiation in Montreal (see Nature 403, $233 ; 2000)$.

The agreement states that bulk shipments of GM foods will be labelled as "containing genetically modified organisms", and that a computer database maintained by the exporter will provide importing countries with information about their contents.

Importers can block shipments, even without "scientific certainty" that a commodity poses a risk.

Environmentalists hailed this as a historic breakthrough - the first time that the so-called precautionary principle has been incorporated in an international agreement.

But the agreement - to be called the Cartagena Protocol, after the Colombian 
- But the agreement - to be called the Cartagena Protocol, after the Colombian city where an earlier round of negotiations ended inconclusively last year - does not claim precedence over the rules of the World Trade

Organization (WTO), and exporters who believe they are being treated unfairly will still have recourse to the WTO.

The Biosafety Protocol is the first treaty based on the Convention on Biological Diversity, established at the Rio Earth Summit in 1992. The United States - the largest exporter of GM food - has not ratified the convention, but it played a leading role in the Montreal negotiations and says that it will abide by the protocol.

Although the protocol was conceived chiefly to control the introduction of living organisms into foreign ecosystems, discussions soon became embroiled in arguments about bulk movements of grain. In Cartagena, the United States and some of its foodexporting allies sought to exclude grain shipments from the protocol, arguing that they posed no environmental or health risk, and that a protocol that included commodities would be used to bar imports of US grain.

But observers say that US and European negotiators at Montreal were under pressure to obtain an agreement after the failure of last November's WTO talks in Seattle. Agricultural biotechnology companies, who had encouraged the US to oppose a protocol covering commodities, were prepared to accept the relatively mild controls on commodity shipments: these will not come into force until two years after the protocol is ratified by 50 countries. Colin Macilwain

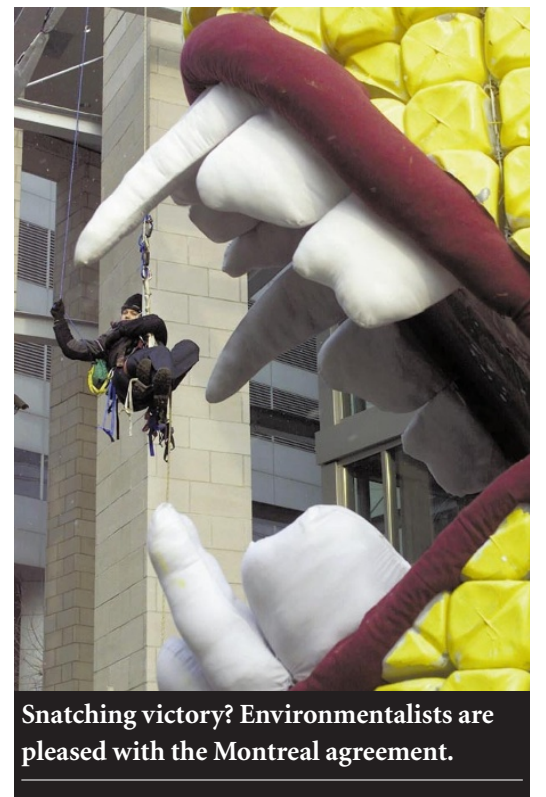

\section{German science begins to cure its historical amnesia}

\section{Berlin}

Documents relating to the Nazi era from the files of Adolf Butenhandt, director of the Kaiser Wilhelm Institute for Biochemistry in Berlin during that time, and later head of the Max Planck Society (MPS), will this week be opened for the first time for examination by historians of science.

The decision to open up the archives reflects a new determination by top MPS officials to come to terms with the wartime activities of scientists who worked for its predecessor, the Kaiser Wilhelm Society (KWS). Butenhandt, who won the Nobel prize for chemistry in 1939 for his work on the isolation of sex hormones and went on to develop the one gene-one enzyme hypothesis, is widely revered as a hero of postwar German science.

Although the KWS lost many of its scientific élite during the Third Reich, when Jews and other 'undesirables' were expelled, the MPS has only recently started to address the role of those remaining scientists in supporting Nazi policy. Many continued their careers in the MPS and in universities after the war, and effectively blocked enquiries into their activities and those of their colleagues during the Third Reich. Investigations became taboo.

The taboo is now ending. The MPS has contracted a group of researchers to examine the role of KWS scientists in developing and supporting Nazi policies, and Butenandt's files, which were to have remained closed in the MPS archives for 30 years after his death in 1995, are being made available to them.

But tensions remain. Last week, Robert Proctor, a historian of science from Pennsylvania State University who is working as a guest scientist with the German historians, was refused access to the archives on the grounds that the files had not been properly indexed. However, after intervention from senior MPS officials, Proctor has been assured of access this week.

The MPS's actions contrast with its defensive stance during the 1980s when concerns were raised that, as head of the Berlin institute during the Second World War, Butenandt knew about - and therefore passively colluded with - research on human subjects that members of the KWS were carrying out.

Proctor, whose books include the recently published The Nazi War on Cancer (Princeton University Press, 1999), says that historical reflection can only help to normalize perspectives, and he applauds the action

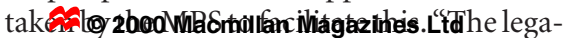
cy of Nazism influences the negative attitude many Germans show towards genetics today, and is probably responsible for the absence of a prominent science-orientated intellectual élite: where are the Goulds, Hawkings and Dawkins of Germany?" he asks.

\section{Turning a blind eye}

One outspoken critic of the veil of silence that he claims the postwar scientific community drew over the Nazi period is Benno Müller-Hill, a professor of genetics at the University of Cologne. He argues that "it is hard to imagine that a talented science administrator like Butenandt" could not have known, for example, that his colleague Günther Hillmann had analysed blood samples at his Institute for Biochemistry for an experiment at the Auschwitz concentration camp.

Müller-Hill had found evidence that Otmar Freiherr von Verschuer, director of the Kaiser Wilhelm Institute for Anthropology, Human Genetics and Eugenics in Berlin after 1942, worked with Josef Mengele on experiments to identify the hereditary aspects of resistance to infectious diseases.

The experiments involved infecting twins - mostly Jewish — with typhus or tuberculosis and observing the resulting pathologies. Blood samples were sent for analysis to Hillmann, who studied the 'defence enzymes' now known not to exist, but thought at the time to confer resistance to disease (see Nature 393, 109-111; 1998).

Müller-Hill was threatened with lawsuits by Butenandt and some of his influential former pupils before he published details of the Hillmann connection in his 1984 book Tödliche Wissenschaft (Murderous Science). But the lawsuits did not materialize. And Hubert Markl, the current MPS president, has acted to ensure that the society examines its past systematically, partly in response to pressure from the society's new generation of science historians.

In particular, the MPS is supporting a five-year research programme, 'The Kaiser Wilhelm Society during National Socialism', being carried out by seven external historians of science, and by visiting scientists. The group, headed by Doris Kaufmann, a professor of history at the Technical University of Berlin, started its work last year.

"The MPS had certainly been reluctant to dig into the details of its 'dark time'", says Kaufmann. She points out, for example, that only 50 pages in a 1,000-page 'Festschrift' commemorating 75 years of the KWS/MPS relates to the period 1933-45. "It's embarrassing."

Kaufmann insists that "we don't want to 